\title{
EVALUATION OF THE FOREST RESOURCE INSPECTION ACTIVITY IN MEXICO
}

\section{EVALUACIÓN DE LA ACTIVIDAD DE INSPECCIÓN DE RECURSOS FORESTALES EN MÉXICO}

\author{
Jesús Ignacio Castro Salazar'* José Raúl Luyando Cuevas²
}

\section{ABSTRACT}

\begin{abstract}
-nvironmental inspectors are an important part of environmental governance -because of their work monitoring compliance with forestry legislation. Mexico is internationally recognized for its large forest territory. Protected Natural Areas are an instrument in the conservation of forest resources. The paper presents an evaluation of the forest resource inspection activity in Mexico, in terms of the personnel authorized to carry out such work and constraints on taking care of the resources. The information was obtained from official databases on the number of inspectors, activities carried out and protected areas. It was noted that the number of inspectors assigned to monitor forestlands has not grown along with the greater number of hectares to be monitored, although complaints and forest deterioration have continued and even increased.
\end{abstract}

Keywords: Inspectors, forest resources, protected natural areas.

\footnotetext{
'Tecnológico Nacional de México/ITS de Abasolo. Blvd. Cuitzeo de los Naranjos núm. 401, Col. Cuitzeo de los Naranjos. C. P. 36976. Abasolo, Guanajuato. México.

Universidad Autónoma de Nuevo León, Instituto de Investigaciones Sociales, Av. Lázaro Cárdenas Ote. y Paseo de la Reforma s/n, Campus Mederos, UANL. Monterrey, N. L. México.

*Corresponding author: jicastrol3@hotmail.com
}

Received: January 11, 2019 / Accepted: September 19, 2019

Please cite this article as follows (APA 6): Castro Salazar, J. I., \& Luyando Cuevas, J. R. (2020). Evaluation of the forest resource inspection activity in Mexico. Textual, 75, 11-35. doi: 10.5154.r.textual.2019.75.01 


\section{RESUMEN}

os inspectores ambientales son parte importante de la gobernanza ambiental por su labor de vigilar el cumplimiento de la legislación en materia forestal. México es reconocido a nivel internacional por su amplia extensión territorial forestal. Las Áreas Naturales Protegidas son un instrumento en la conservación de recursos forestales. El artículo presenta una evaluación de la actividad de inspección de los recursos forestales en México, en términos del personal autorizado para efectuar dicha labor y limitantes de incidencia para cuidar los recursos. La información fue obtenida en bases de datos oficiales sobre el número de inspectores, actividades ejecutadas y áreas protegidas. Se apreció que el número de inspectores asignados para vigilar los terrenos forestales no ha crecido a la par del mayor número de hectáreas a vigilar, pese a que las denuncias y el deterioro forestal ha continuado e inclusive incrementado.

Palabras clave: Inspectores, recursos forestales, áreas naturales protegidas.

\section{INTRODUCTION}

Proper management of Natural Resources (NR) is crucial for the development of any society. In order to have an efficient and effective management, it is necessary to have a legislative framework that regulates and governs the conditions under which it should be implemented. Subsequently, a strategy must be generated to verify compliance with the established regulations. In general, in non-developed countries inadequate attention is paid to inspections, as Wingqvist, Slunge, Drakenberg, Sjöstedt, and Ekbom (2012) point out, indicating that in developing countries or countries in transition, environmental agencies do not effectively use their scarce human and administrative resources in functions such as monitoring, control and supervision, with the objective of complying with regulations.

\section{INTRODUCCIÓN}

La adecuada gestión de los Recursos Naturales (RN) es de fundamental importancia para el desarrollo de toda sociedad. Para llevarla a cabo de manera eficiente y efectiva es necesaria la existencia de una legislación que regule y norme las condiciones en que se deberá implementar. Posteriormente, generar una estrategia que verifique el cumplimiento de la normatividad instaurada. En general, en los países no desarrollados se le presta inadecuada atención a la realización de inspecciones, como bien lo señalan Wingqvist, Slunge, Drakenberg, Sjöstedt, y Ekbom (2012), al indicar que en los países en desarrollo o en transición, las agencias ambientales no utilizan de forma efectiva sus escasos recursos humanos y administrativos en funciones como el monitoreo, el control y la supervisión, con el objetivo de dar cumplimiento a la normatividad. 
Regarding forest resources, the magnitude of their degradation ${ }^{1}$ has prompted governments to intensify their analysis of the causes of illegal exploitation, concluding what seems to be obvious: the problem is related to poor compliance with legislation, among other factors. Consequently, efforts must be aimed at improving forest monitoring and strengthening national institutional capacities to enforce the law, in order to obtain positive results (Food and Agriculture Organization [FAO], 2010a).

Inspectors are the ones who physically verify compliance, or not, with environmental regulations and, therefore, are the most important actors in protecting forests, as they are the guarantors of the implementation of the regulations (Pautz, 2009; Pautz \& Rinfret, 2011). They are the most visible representatives of the State before society, so their performance must be under constant scrutiny as the high costs of poor inspection practices affect economic performance and the quality of governance. As noted by the Organization for Economic Cooperation and Development (OECD) (2004), inspectors in institutions enforcing environmental regulations must increase the effectiveness and efficiency of their actions.

The policies and strategies in the management of NRs in Mexico are based on the Mexican Constitution. Specifically, article 27 states that the exploitation or use

'The United Nations states: "Global deforestation continues at an alarming rate: 7 million hectares of forest are destroyed every year, an area roughly the size of Portugal" (UN, 2018a).
En el caso específico del tema forestal, la magnitud de su degradación ${ }^{1}$ ha impulsado a los gobiernos a intensificar el análisis de las causas de su explotación ilegal, llegando a lo que parece evidente, el problema está relacionado con la escasa observancia de la legislación, entre otros factores, por lo que se deben encaminar esfuerzos para mejorar la vigilancia de bosques y fortalecer las capacidades institucionales nacionales para observar las leyes, a fin de obtener resultados positivos (Food and Agriculture Organization [FAO], 2010a).

Los inspectores son quienes verifican en físico para determinar el cumplimiento o no de las reglamentaciones ambientales y, por ello, son los actores más importantes en su protección, al ser garantes de la implementación de las regulaciones (Pautz, 2009; Pautz \& Rinfret, 2011). Son los representantes más visibles del Estado ante la sociedad, por lo que, su desempeño debe ser objeto de un escrutinio constante a medida que los altos costos de las malas prácticas de inspección afectan el desempeño económico y la calidad de la gobernanza. Como señala la Organization for Economic Cooperation and Development (OECD, por sus siglas en inglés) (2004), es necesario que los inspectores de las instituciones que aplican la ordenanza ambiental aumenten su eficacia y eficiencia en las acciones que desempeñan

'Las Naciones Unidas señalan que: "La deforestación mundial continúa a un ritmo alarmante: cada año se destruyen 7 millones de hectáreas de bosque, un área aproximadamente del tamaño de Portugal" (traducción propia de UN, 2018a). 
of NRs, by individuals or companies, can only be carried out through concessions granted by the Federal Executive. In view of this, NR management is mainly the purview of the federation. Likewise, Mexico has specific laws to regulate forest resources: General Law of Ecological Equilibrium and Environmental Protection (LGEEPA, for its initials in Spanish) (the most important environmental law in force), General Law of Sustainable Forest Development (LGDFS, for its initials in Spanish) and its regulations, LGEEPA's Regulations on Environmental Impact Assessment (EIA) and LGEEPA's Regulations on Protected Natural Areas (PNA).

In this sense, it is the inspectors of the Federal Prosecutor's Office for Environmental Protection (PROFEPA, for its initials in Spanish) who are responsible for monitoring, inspecting and verifying compliance with environmental legal provisions; thus, PROFEPA becomes a key institution for forest NR policy and management (Lezama, 2010). In order to exercise its powers, PROFEPA has administrative units distributed throughout the country (Article 68 of the Internal Regulations of the Ministry of Environment and Natural Resources [SEMARNAT, for its initials in Spanish], 2012). In each of them, the inspectors have the authority to scrutinize and monitor various areas, including forest resources. For example, in 2014, they were responsible for inspecting and monitoring 176 PNAs (located in forest areas), 141.7 million hectares of vegetated area (out of which 57 million hectares correspond to forests and jungles) and 10844 Forest Raw Material Storage and Transfor-
Las políticas y estrategias en la gestión de RN en México están sustentadas en la Constitución Política de los Estados Unidos Mexicanos. Por ejemplo, el artículo 27 señala que la explotación, el uso o el aprovechamiento de los RN, por particulares o sociedades, no podrá realizarse sino mediante concesiones otorgadas por el Ejecutivo Federal. Ante ello, la gestión de RN, en su mayoría, es competencia de la federación. Asimismo, México tiene leyes específicas para regular los recursos forestales: Ley General del Equilibrio Ecológico y la Protección al Ambiente (LGEEPA) (ley ambiental vigente más importante), Ley General de Desarrollo Forestal Sustentable (LGDFS) y su reglamento, Reglamento de la LGEEPA en materia de Evaluación del Impacto Ambiental (EIA) y Reglamento de la LGEEPA en materia de Áreas Naturales Protegidas (ANP).

En este sentido, son los inspectores de la Procuraduría Federal de Protección al Ambiente (Profepa) los encargados de vigilar, inspeccionar y verificar el cumplimiento de las disposiciones legales ambientales, por tanto, la Profepa se vuelve una institución clave para la política y gestión de los RN forestales (Lezama, 2010). Para el ejercicio de sus atribuciones, la Procuraduría cuenta con unidades administrativas (delegaciones), distribuidas a lo largo del país (artículo 68 del Reglamento interior de la Secretaría de Medio Ambiente y Recursos Naturales [Semarnat], 2012). En cada una, los inspectores tienen atribuciones de escrutinio y vigilancia en diversas materias, incluyendo recursos forestales. Por ejemplo, en el año 2014, fueron responsables de inspeccio- 
mation Centers (CAT, for its initials in Spanish) (National Council for the Evaluation of Social Development Policy [CONEVAL, for its initials in Spanish], 2014).

However, the importance of inspections as an essential task is little studied in Mexico (OECD, 2014a). Knowing the performance of inspectors would allow for a better idea of what is happening in the field and, with the data obtained, institutional objectives could be better planned. The aim of this study is to evaluate the forest NR inspection activity in Mexico, in terms of the personnel authorized to carry out such work in the field and some constraints on the care of such resources.

\section{CURRENT SITUATION OF THE FOREST SECTOR IN MEXICO}

Mexico has the twelfth largest forest area in the world and the third largest in Latin America, with 138 million hectares, representing $70.3 \%$ of the national territory (Comisión Nacional Forestal [CONAFOR], 2014). And although Mexico has a legal framework supporting forest policy and management, the country has one of the highest rates of deforestation in the world, ranging from 75000 to 1.98 million hectares per year, a situation partially caused by the unsustainable use of forest resources (Torres-Rojo, 2004). The catastrophe is so notorious that Mexico has been considered among the 15 countries with the highest levels of deforestation worldwide, and the fifth in Latin America so far this century; from 2010 to 2016, it lost 270000 hectares of forest and 3.10 million hectares of tree cover (Global Fo- nar y vigilar 176 ANP (ubicadas en zonas forestales), 141.7 millones de hectáreas de superficie vegetal (de las cuales 57 millones de hectáreas corresponden a bosques y selvas) y 10844 Centros de Almacenamiento y Transformación de Materias Primas Forestales (CAT) (Consejo Nacional de Evaluación de la Política de Desarrollo Social [CONEVAL], 2014).

No obstante, la importancia de las inspecciones como una labor imprescindible, es un tema poco estudiado en México (OECD, 2014a). Conocer el desempeño de los inspectores permitiría tener una mejor idea de lo que sucede en campo y con los datos obtenidos se podría planificar de mejor manera los objetivos institucionales. El interés de este estudio es evaluar la actividad de inspección de RN forestales en México, en términos del personal autorizado para efectuar dicha labor en campo y algunas limitantes de incidencia para el cuidado de esos recursos.

\section{SITUACIÓN DEL SECTOR FORESTAL EN MÉXICO}

El territorio mexicano ocupa el doceavo lugar a nivel mundial en superficie forestal y tercero en América Latina, con 138 millones de hectáreas, que representan el $70.3 \%$ del territorio nacional (Comisión Nacional Forestal [Conafor], 2014). Y aunque México cuenta con una legislación y reglamentos que apoyan la política y gestión forestal, el país se encuentra entre los primeros lugares en altas tasas de deforestación a nivel mundial, con rangos que oscilan entre los 75000 y 1.98 millones de hectáreas por año, situación cau- 
rest Watch, 2016). Between 1990 and 2015 there was a loss of forest area, other wooded land and living biomass within forests (Table 1). Despite interest in increasing the planted forest area, this has not been significant compared to the trend in forest hectare losses.

Forest inspection becomes more relevant when considering that timber production was an activity carried out, although with fluctuating intervals, almost constantly from 2005 to 2016; from 2014 to 2016 there was an increase in production from 5665 to 6325 thousand cubic meters in logs, respectively (Instituto Nacional de Estadística y Geografía [INEGI], 2017a). Another productive activity carried out almost constantly was non-timber production in forestlands, with almost constant increases from 1997 to 2012, increasing from 45500 to 142035 tons produced per year, respectively (SEMARNAT, 2018).

As a strategy for forestland conservation, from 2000 to 2016 the number of PNAs increased, as did their area, rising sada, en parte, por el uso no sustentable de los recursos forestales (Torres-Rojo, 2004). La catástrofe es tan notoria, que México ha sido considerado uno de los 15 países con niveles más altos de deforestación a nivel mundial y el quinto en América Latina, en lo que va del siglo, dado que del año 2010 al 2016 perdió 270 000 hectáreas de bosque y 3.10 millones de hectáreas de cobertura arbórea (Global Forest Watch, 2016). Entre los años 1990 y 2015 se apreció pérdida de extensión de bosques, de otro tipo de tierras boscosas y de biomasa viva dentro de los bosques (Cuadro 1). Pese al interés por incrementar la extensión de los bosques plantados, esto no ha llegado a ser significativo, en comparación a la tendencia en pérdidas de hectáreas de bosque.

La inspección forestal cobra más relevancia al considerar que del 2005 al 2016 la producción forestal fue una actividad realizada, si bien con intervalos fluctuantes, casi de una manera constante, del año 2014 al 2016 se vio un incremento en la producción, pasando de 5665 a $6325 \mathrm{mi}$ -

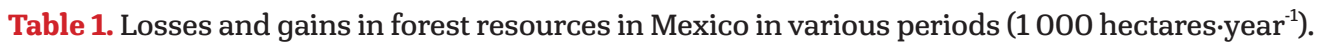
Cuadro 1. Pérdida y ganancia de recursos forestales en México en diversos periodos (1000 hectáreas·año $\left.{ }^{-1}\right)$

\begin{tabular}{ccccc}
\hline $\begin{array}{c}\text { Period/ } \\
\text { Periodo }\end{array}$ & $\begin{array}{c}\text { Forest area/ } \\
\text { Extensión de } \\
\text { bosques }\end{array}$ & $\begin{array}{c}\text { Other wooded land/ } \\
\text { Otro tipo de tierras } \\
\text { boscosas }\end{array}$ & $\begin{array}{c}\text { Living forest biomass/ } \\
\text { Biomasa viva de los } \\
\text { bosques }\end{array}$ & $\begin{array}{c}\text { Planted forest/ } \\
\text { Bosque plantado }\end{array}$ \\
\hline $1990-2000$ & -190.4 & -41.6 & -10.0 & 3.2 \\
$2000-2010$ & -135.8 & -51.6 & -8.1 & 2.4 \\
$2010-2015$ & -148.8 & -72.2 & -4.0 & 5.6 \\
\hline
\end{tabular}

Source: Prepared by authors with information obtained from FAO (2015).

Fuente: Elaboración propia con información obtenida de FAO (2015). 
from 17057000 to $90638000^{2}$ hectares, respectively (SEMARNAT, 2018; INEGI, 2017b). Increasing PNAs is a national commitment, since in 2015 Mexico was one of the ten countries with the most forest areas designated as a priority for biodiversity conservation, with Mexico ranking third with 28049000 hectares (FAO, 2016). This commitment brought with it inspection responsibilities, in the sense of supervising the transformation in those areas as stipulated in the applicable forestry legislation (LGEEPA, LGDFS and regulations, and the LGEEPA's regulation regarding PNAs, mainly).

Although PROFEPA is responsible for carrying out inspections and monitoring compliance with regulations on forest resources (timber and non-timber) outside and within the PNAs, as "an act of authority, supported by the law, whose purpose is to verify the legality and compliance with the licenses, permits and authorizations issued by the competent authorities to individuals, companies, social groups and even to the government authorities and entities themselves" (PROFEPA, 2010), there are still problems regarding the degradation of nature within the PNAs (Ortega-Rubio, Pinkus-Rendón, \& Espitia-Moreno, 2015).

The National Council for the Evaluation of Social Development Policy (CONEVAL) analyzed the subject of inspectors in PROFEPA in 2014. This analysis consisted of an evaluation of the Inspection and Survei-

${ }^{2}$ Data from INEGI (2017b) are described as preliminary figures. les de metros cúbicos en rollo, respectivamente (Instituto Nacional de Estadística y Geografía [INEGI], 2017a). Otra actividad productiva realizada casi de manera constante fue la producción forestal no maderable de tierra de monte, con incrementos casi constantes desde el año 1997 hasta el 2012, pasando de una producción de 45500 a 142035 toneladas al año, respectivamente (Semarnat, 2018).

Como estrategia para la conservación de terrenos forestales, desde el año 2000 al 2016 aumentó el número y superficie de ANP, de 17057000 hectáreas a $90638000^{2}$ hectáreas, respectivamente (Semarnat, 2018; INEGI, 2017b). El incremento de ANP es un compromiso nacional, pues en el año 2015, México fue uno de los diez países con más áreas boscosas designadas prioritarias para la conservación de biodiversidad, ocupó el tercer lugar, con 28049000 hectáreas (FAO, 2016). Compromiso que trajo responsabilidades en materia de inspección, en el sentido de supervisar la transformación en esas áreas, según lo estipulado en la legislación forestal aplicable (LGEEPA, LGDFS y su reglamento, y el Reglamento de la LGEEPA en materia de ANP, principalmente).

Y aunque la Profepa es la responsable de inspeccionar y vigilar el cumplimiento de la normativa en recursos forestales (maderables y no maderables) fuera $\mathrm{y}$ dentro de las ANP, como "un acto de autoridad, sustentado por la ley, cuyo fin es ve-

${ }^{2}$ Datos presentados por INEGI (2017b) son descritos como cifras preliminares. 
llance Program in the Environment and Natural Resources area, seeking to know the protection coverage provided to that natural capital. To this end, NR indicators were used as percentages of: 1) operations performed; 2) surveillance visits carried out; 3) inspection actions; and 4) public servants to attend to public complaints. The results show that 10140 inspections and 7449 surveillance activities related to NRs were carried out from January to December 2013. It is also mentioned most citizen complaints dealt with forest issues, accounting for 2652 complaints (37\% of the total)

Despite agreements signed, agencies established and the enactment of laws to protect natural capital, there are still examples and situations indicating the lack of oversight of NRs. In the specific case of forest resources, in the Natural Resources Protection Areas of the Valle de Bravo, Malacatepec, Tilostoc and Temascaltepec river basins, clandestine logging is a current problem. In the Sierra Gorda Biosphere Reserve, there are reduced areas of tropical sub-deciduous forest and vegetation. In Sacromonte National Park, there is a reduction in surface area due to invasion by irregular human settlements (Arriola-Padilla, 2015). Similarly, in the Monarch Butterfly Biosphere Reserve, erosion can be seen on trails due to the use of horses and hikes by a high number of tourists visiting the area (Espitia-Moreno, Jiménez-Sierra, \& Ortega-Rubio, 2015). Another problem in the forests is illegal logging (Galicia, 2013), an activity that is carried out anarchically and causes deforestation and degradation. "Inventories rificar la legalidad y cumplimiento de las licencias, permisos y autorizaciones emitidas por las autoridades competentes a los particulares, empresas, agrupaciones sociales y aún a las propias autoridades y entidades del gobierno" (Profepa, 2010), se siguen apreciando problemáticas en materia de degradación de la naturaleza al interior de las ANP (Ortega-Rubio, Pinkus-Rendón, \& Espitia-Moreno, 2015).

El tema de los inspectores en la Profepa fue analizado en el año 2014 por el Consejo Nacional de Evaluación de la Política de Desarrollo Social (CONEVAL), mediante un diagnóstico al Programa de Inspección y Vigilancia en materia de Medio Ambiente y Recursos Naturales -buscando conocer la cobertura de protección que tiene el capital natural-. Para lo cual, se utilizaron indicadores en materia de RN como porcentajes de: 1) operativos realizados; 2) recorridos de vigilancia realizados; 3 ) acciones de inspección; y 4) servidores públicos para atender la denuncia popular. Los resultados destacan que en materia de $\mathrm{RN}$-en el periodo de enero a diciembre 2013- se realizaron 10140 inspecciones y 7449 acciones de vigilancia. También se menciona que la mayor proporción de denuncias ciudadanas atendidas correspondió a cuestiones en materia forestal, con un total de 2652 denuncias (37 \% del total).

Pese a convenios firmados, dependencias generadas y la creación de leyes para proteger el capital natural, siguen existiendo ejemplos y situaciones que denotan la falta de vigilancia de RN. En el caso concreto del recurso forestal, en el Área de Protección de Recursos Naturales 
carried out in Mexico in 1990 and 2000 estimated losses between 36000 and 45000 hectares per year, due to deforestation." The Foro Ambiental (2017) indicates that: "Illegal logging in Mexico is a crime that is committed daily, with almost absolute impunity, and even in broad daylight it is common to see dozens of trucks transporting wood along the country's various highways. The same Forum also warns: "According to the Greenpeace environmental organization, $70 \%$ of the 5.8 million cubic meters of forest resources produced in Mexico have an illegal origin, which demonstrates the seriousness of the problem, but also shows the few or no actions taken by the authorities to stop illegal logging." Above all, it shows the lack of enforcement of forest laws that leads us to value the work that PROFEPA's inspectors should do, but also the insufficient actions taken by the authorities to address this problem.

\section{ENVIRONMENTAL GOVERNANCE AS A THEORETICAL CONCEPT FOR ANALYZING INSPECTION}

In environmental matters, governance is seen as the process of formulating and refuting designs, and implementing procedures and practices that shape access, control and use of NRs among different actors (de Castro, Hogenboom, \& Baud, 2015). The UN (2018b) states: "Environmental governance is key... Therefore, the decision-making processes and the work of institutions must follow informed, coherent, unified and comprehensive methods and, at the same time, be supported by adequate regulatory frameworks that
Cuencas de los Ríos Valle de Bravo, Malacatepec, Tilostoc y Temascaltepec, existen problemas de tala clandestina. En la Reserva de la Biosfera Sierra Gorda se aprecian áreas reducidas de bosque tropical subcaducifolio y vegetación. En el Parque Nacional de Sacromonte se aprecia una reducción de superficie debido a la invasión de asentamientos humanos irregulares (Arriola-Padilla, 2015). En situaciones similares, en la Reserva de la Biosfera de la Mariposa Monarca se aprecia erosión en senderos debido al uso de caballos y caminatas, por la cantidad de turistas que visitan el lugar (Espitia-Moreno, Jiménez-Sierra, \& Ortega-Rubio, 2015). Aunado a que el principal problema en materia forestal, Galicia (2013), es la tala ilegal, actividad que se realiza anárquicamente y provoca deforestación y degradación. "Los inventarios realizados en México en 1990 y 2000 estimaron pérdidas de entre 36 mil y 45 mil hectáreas anuales, debido a la deforestación". El Foro Ambiental (2017) señala que: "La tala ilegal de árboles en México es un delito que se comete a diario, con impunidad casi absoluta, e incluso a plena luz del día es común observar decenas de camiones que transportan madera por las diversas carreteras del país". Además de advertir que "De acuerdo con la Organización Ecologista Greenpeace, de los 5.8 millones de metros cúbicos de recursos forestales producidos en México, el $70 \%$ es de procedencia ilegal, lo que demuestra la gravedad del problema, pero también pone en evidencia las pocas o nulas acciones de las autoridades para frenar la tala ilegal de árboles". Sobre todo, la falta de aplicación de las leyes sobre el tema que nos lleva a valorar la labor que 
facilitate these processes." The concept is used to define processes adopted by States for the efficient administration of their environment-related institutions, where the interaction among institutions, regulatory processes and governance actors (such as authorities) are fundamental (Hernández, 2012).

NR governance is exercised through formal institutions (such as constitutional and legal frameworks); regulatory aspects and the implementation of public policies are among the challenges to be addressed (Altomonte \& Sánchez, 2016). The success of forest governance, including law enforcement, requires political commitment and efforts in key areas that help to achieve better results, such as: a) improved forest monitoring, and b) strengthened national institutional capacities to enforce laws (FAO, 2010b).

While regulatory compliance is an important element in protecting the environment, inspections are a key part of compliance. They are an element used by authorities to enforce regulations and can be a source of information to determine whether a law is really effective and valuable (Monk, 2012). Thus, inspections are one of the most important tasks in enforcing regulations and ensuring their compliance, since they are an important factor in enabling a society to trust the government to achieve the desired policy outcomes (Jacobs \& Cordova, 2005; OECD, 2014b).

Among the Principles of Good Practice for Regulatory Compliance and Inspec- debieran hacer los inspectores de la Profepa, pero también las insuficientes acciones tomadas por las autoridades para atacar esta problemática.

\section{LA GOBERNANZA AMBIENTAL COMO CONCEPTO TEÓRICO PARA ANALIZAR LA INSPECCIÓN}

En materia ambiental, la gobernanza es vista como el proceso de formulación y refutación de diseños y ejecución de procedimientos y prácticas que configuran el acceso, control y uso de los RN entre diferentes actores (de Castro, Hogenboom, \& Baud, 2015). Las UN (2018b). señalan que: "La gobernanza ambiental es clave... Por ello, los procesos de toma de decisiones y el trabajo de las instituciones deben seguir métodos informados, coherentes, unificados e integrales y, al mismo tiempo, deben apoyarse en marcos normativos adecuados que faciliten estos procesos". El concepto se utiliza para definir procesos adoptados por los Estados para la administración eficiente de sus instituciones en asuntos ambientales, donde la interacción entre instituciones, procesos de regulación y actores de la gobernanza (como autoridades) son parte fundamental (Hernández, 2012).

La gobernanza de RN se ejerce, por medio de instituciones formales (como marcos constitucionales y legales); entre los desafíos a ser atendidos están los aspectos regulatorios e implementación de políticas públicas (Altomonte \& Sánchez, 2016). El éxito de la gobernanza forestal, incluyendo la aplicación de la ley, requiere de un compromiso político y esfuerzos en 
tions, the OECD (2018) states that the inspection system, including the institutions in charge, must function as it should: in terms of stakeholder satisfaction, efficiency (benefits/costs) and effectiveness (environmental protection). But measuring the effectiveness and efficiency of inspections is not simple or direct, since it is not always obvious what should be achieved in terms of public goods (Blanc, 2012). On the other hand, defining the quality of inspection is not easy either because this method is only part of a larger and more complex legal system.

Regular performance monitoring of the inspection institutions is essential for the good operation of the system and its improvement through a variety of means, and according to data availability (such as official statistics), in order to know the efficiency (such as costs) and effectiveness (environmental protection) (OECD, 2018). Among the minimum quality standards for environmental inspections, the importance of ensuring human and financial resources, including at least a thorough assessment of the personnel needed to carry out their duties and achieve the policy objectives, stands out in a first phase (OECD, 2004). Therefore, management indicators are useful to clarify objectives (Guinart, 2003), which would serve to answer questions such as: how much do inspections cost (to the State) and what kind of results are they obtaining or reporting? (Blanc, 2012).

There are different tools to evaluate inspections. The quantitative ones are áreas clave que ayuden a obtener mejores resultados, tales como: a) mejorar el monitoreo forestal y b) fortalecer las capacidades institucionales nacionales para hacer cumplir las leyes (FAO, 2010b).

Si bien el cumplimiento normativo es un elemento importante para proteger el ambiente, son las inspecciones pieza clave del cumplimiento. Son un elemento utilizado por las autoridades para aplicar la reglamentación y pueden ser fuente de información para determinar si una ley es realmente efectiva y valiosa (Monk, 2012). Por tanto, las inspecciones son una de las tareas más importantes para hacer cumplir las regulaciones y garantizar la observancia de las normas, dado que son un factor importante para que una sociedad pueda confiar en el gobierno y este pueda lograr los resultados de política deseados (Jacobs \& Cordova, 2005; OECD, 2014b).

Entre los Principios de Buenas Prácticas para el Cumplimiento de Reglamentaciones e Inspecciones, la OECD (2018) menciona que el sistema de inspección, incluyendo a las instituciones a cargo, deben desempeñase como es debido: en términos de satisfacción de los interesados, eficiencia (beneficios/costos) y efectividad (como protección del ambiente). Pero la medición de efectividad y eficiencia de las inspecciones no es simple ni directa, pues no siempre es obvio lo que se debe lograr en términos de bienes públicos (Blanc, 2012). Por otra parte, definir la calidad de la inspección tampoco es fácil, porque este método solo es parte de un sistema legal más grande y complejo. 
mainly based on official data available on inspections to ensure knowledge about the problems encountered and are also indispensable if improvements, changes and adaptations are to be made throughout the process (Blanc, 2012). This is a difficult situation to achieve in Mexico since, in practice, the conditions for creating indicators that allow for constant and appropriate monitoring are not observed. In addition, there are not enough data to adequately assess the individual performance of inspections and the results obtained. In view of this, the investigation will be adapted to available data, but with the perspective of achieving the best possible analysis of the situation of inspection and inspectors in the country.

This study was conducted with INEGI databases (2016) on PNA hectares in the country in $2016^{3}$. Information was also obtained through the Federal Transparency and Access to Public Information Act (LFTAIP, for its initials in Spanish, 2017) on forestry matters on the number of a) inspections, b) operations, c) visits, d) inspectors, and e) complaints ${ }^{4}$. Finally, interviews were conducted with PROFEPA's inspectors in the Bajío area.

\footnotetext{
${ }^{3}$ There is information for 2017 on hectares of PNAs (INEGI, 2017b), but it was not used as it is presented as preliminary.

${ }^{4}$ Data were requested from 1992 (the year PROFEPA started operating). An official reply indicated that the number of inspectors had only been recorded since 2006 and that the number of complaints had only been recorded since 2010.
}

Es indispensable monitorear regularmente el desempeño de las instituciones de inspección para el buen funcionamiento del sistema y su mejora a través de una variedad de medios, y según la disponibilidad de datos (como estadísticas oficiales), a fin de conocer la eficiencia (como costos) y efectividad (protección ambiental) (OECD, 2018). Entre los estándares mínimos de calidad para las inspecciones ambientales destaca en una primera fase la importancia de garantizar recursos humanos y financieros, donde al menos se incluya una evaluación exhaustiva del personal necesario para llevar a cabo sus funciones y alcanzar los objetivos políticos (OECD, 2004). Por tanto, los indicadores de gestión son útiles para clarificar objetivos (Guinart, 2003), que servirían para responder a interrogantes como: ¿Cuánto cuestan las inspecciones (al Estado) y qué clase de resultados están dando o entregan? (Blanc, 2012).

Existen diferentes herramientas para evaluar las inspecciones. Las cuantitativas se basan, principalmente, en datos oficiales disponibles sobre inspecciones para garantizar un conocimiento sobre los problemas encontrados, siendo también indispensables si se quieren realizar mejoras, cambios y adecuaciones a lo largo del proceso (Blanc, 2012). Situación difícil de realizar en México, pues en la práctica no se observan las condiciones para crear indicadores que permitan realizar un monitoreo constante y de manera apropiada. Además, no existen datos suficientes para explorar adecuadamente el desempeño individual de inspecciones y los resultados obtenidos. Ante ello, la in- 


\section{RESULTS AND DISCUSSION}

The budget assigned to PROFEPA is divided into the following areas: 1) personal services, 2) basic services, 3) environmental auditing area, 4) industrial inspection area, 5) legal area, 6) NR area, 7) staff and 8 ) investment. The first two added up to 85 $\%$ of the resources allocated for 2010 , and $91 \%$ for 2016. In other words, they represent the largest percentage of the budget assigned to this unit, and their resources are basically destined to, firstly, salaries, wages, per diems, fees, benefits, social security expenses, and other benefits derived from an employment relationship (which may be of a permanent or transitory nature). Secondly, the budget was allocated to postal, telephone, electricity, water, data transmission, radio communications and other similar services. The remaining 15 and $9 \%$ were assigned to items related to building (residential and non-residential), construction for services supply and construction sites, installation and equipment in construction sites, finishing, maintenance and rehabilitation of buildings; materials and supplies (materials, stationary items and minor office equipment, printing and reproduction, information and communication technologies), cleaning materials; fuels, lubricants and additives for land, air, sea, lake and river vehicles intended for public services; medicines and pharmaceutical products, medical materials, accessories and supplies; clothing and uniforms, personal protective clothing; minor tools, spare parts and minor accessories for buildings; and national per diems for field work and supervision, comprehensive travel and vestigación se adecuará a datos disponibles, pero con la perspectiva de lograr el mejor análisis posible de la situación en que se encuentra la inspección y los inspectores en el país.

Se trabajó con bases de datos del INEGI (2016) sobre hectáreas de ANP en el país para el año $2016^{3}$. También se obtuvo información mediante la Ley Federal de Transparencia y Acceso a la Información Pública (LFTAIP, 2017) en materia forestal sobre los números de a) inspecciones, b) operativos, c) recorridos, d) inspectores y e) denuncias ${ }^{4}$. Por último, se retomaron entrevistas realizadas a inspectores de Profepa ubicados en la zona bajío.

\section{RESULTADOS Y DISCUSIÓN}

El presupuesto asignado a Profepa se divide en los siguientes rubros: 1) servicios personales, 2) servicios básicos, 3) área de auditoría ambiental, 4) área de inspección industrial, 5) área jurídica y 6) área de RN, 7) staff y 8) inversión. Los dos primeros, para el año 2010, sumaban el $85 \%$ de los recursos y para el 2016 el $91 \%$, es decir, captan el mayor porcentaje del presupuesto destinado a esta dependencia y son recursos que básicamente se destinan a, en primer lugar, sueldos,

\footnotetext{
${ }^{3}$ Existe información para 2017 sobre hectáreas de ANP INEGI (2017b), pero no se utilizaron pues se presentan como preliminares.

${ }^{4}$ Se solicitaron datos desde 1992 (año en que entró en funciones Profepa). Vía oficio se notificó que del número de inspectores solo contaban con registros a partir del año 2006 y en el caso del número de denuncias solo contaban con información a partir del 2010.
} 
per diem services, services for training public servants, among others. Most of the budget is assigned to cover current expenditures. This fact coincides to a certain extent with the perception of PROFEPA's forest NR inspectors: five of them were interviewed ${ }^{5}$ in the Bajío area, and they listed the lack of economic and material resources as obstacles for carrying out their functions adequately; they also indicated that the lack of training is a current problem. This also agrees with Jacobs and Cordova (2005) who indicate that in the case of Mexico, training programs for inspectors are few and in many cases non-existent, and that when programs do exist, they focus on orienting inspectors on how to use inspection manuals, safety procedures and protective equipment.

In forestry, in relation to the three main functions of inspectors, it was found that inspection actions, visits and operations, since PROFEPA came into operation, tend to fluctuate in frequency (Table 2). The number of inspections grew rapidly until it reached a peak in 1997, after which, also in an oscillating manner, a decreasing trend was observed. This trend is worrying, since inspections are of vital importance to protect NRs, since they are one of the main instruments to detect anomalies and punish possible infringements of environmental legislation. By 2016 the number of inspections fell by more than half of the number at the peak (without considering the year in which the unit began

${ }^{5}$ Interviews conducted the first week of August 2018, in Guanajuato. salarios, dietas, honorarios, prestaciones, gastos de seguridad social, y otras prestaciones derivadas de una relación laboral (pudiendo ser de carácter permanente o transitorio). En segundo lugar, el presupuesto se destinó a servicios tales como postal, telefónico, energía eléctrica, agua, transmisión de datos, radiocomunicaciones y otros análogos. Mientras que el otro 15 y 9 \% se destinó a rubros relacionados con edificación (habitacional y no habitacional), construcción para abastecimiento de servicios y obras, instalación y equipamiento en construcciones, acabados, mantenimiento y rehabilitación de edificios, materiales y suministros (materiales, útiles y equipos menores de oficina, de impresión y reproducción, de tecnologías de la información y comunicación), material de limpieza, combustibles, lubricantes y aditivos para vehículos terrestres, aéreos, marítimos, lacustres y fluviales destinados a servicios públicos, medicinas y productos farmacéuticos, materiales, accesorios y suministros médicos, vestuario y uniformes, prendas de protección personal, herramientas menores, refacciones y accesorios menores de edificios, viáticos nacionales para labores en campo y de supervisión, servicios integrales de traslado y viáticos, servicios para capacitación a servidores públicos, entre otros. La mayor parte del presupuesto se destina a gasto corriente. Hecho que coincide en cierto sentido con la percepción que tienen los inspectores de RN forestales de Profepa, en entrevistas ${ }^{5}$ realizadas a cinco de ellos

${ }^{5}$ Entrevistas realizadas en la primera semana de agosto, 2018 en la ciudad de Guanajuato. 
Table 2. Forest-related actions taken by inspectors from 1995 to 2016 in Mexico.

Cuadro 2. Acciones en materia forestal en México por parte de los inspectores de 1995 al 2016.

\begin{tabular}{|c|c|c|c|}
\hline Year/Años & Inspections/Inspecciones & Visits/Recorridos & Operations/Operativos \\
\hline 1995 & 745 & 1898 & 53 \\
\hline 1996 & 5673 & 1679 & 337 \\
\hline 1997 & 7957 & 1551 & 1031 \\
\hline 1998 & 5650 & 1522 & 1013 \\
\hline 1999 & 5189 & 3533 & 2006 \\
\hline 2000 & 6011 & 4605 & 1015 \\
\hline 2001 & 6207 & 6024 & 734 \\
\hline 2002 & 7020 & 5985 & 180 \\
\hline 2003 & 7420 & 249 & 98 \\
\hline 2004 & 7570 & 733 & 167 \\
\hline 2005 & 7015 & 501 & 165 \\
\hline 2006 & 6437 & 805 & 94 \\
\hline 2007 & 6902 & 1003 & 197 \\
\hline 2008 & 6994 & 3042 & 132 \\
\hline 2009 & 7448 & 4158 & 166 \\
\hline 2010 & 5847 & 4122 & 185 \\
\hline 2011 & 5684 & 4141 & 312 \\
\hline 2012 & 3794 & 4147 & 375 \\
\hline 2013 & 4722 & 3396 & 311 \\
\hline 2014 & 4746 & 2684 & 263 \\
\hline 2015 & 3742 & 2096 & 329 \\
\hline 2016 & 3435 & 1241 & 285 \\
\hline
\end{tabular}

Source: Prepared by authors with information obtained from LFTAIP (2017).

Fuente: Elaboración propia con información obtenida a través de la LFTAIP (2017). 
its work). Likewise, the ratio between the inspections carried out and the number of inspectors has a clear downward trend, reaching its lowest point in 2016, when each inspector carried out a lower number of inspections.

With regard to surveillance rounds, there were cyclical trends, from 1995 to 1998 decreasing, for 1999 growing until reaching a peak in 2001, and then showing a decreasing cyclical trend, in which the years 2003, 2004, 2005 and 2006 can be highlighted where surveillance rounds were particularly low (while inspections increased). The lowest number of inspections $^{6}$ was carried out in the year PROFEPA began operations and the highest was in 1999. There was a period when these were particularly high, from 1997 to 2000; after this last year the number of operations was lower than those carried out in the aforementioned period.

A partial correlation was run between inspections with visits and operations, in order to understand exactly the relationship between the variables of interest. A coefficient was obtained between inspections and operations of -0.44 , which is significant at $95 \%$, i.e. there is a negative relationship between these two variables, since when one increases the other

\footnotetext{
${ }^{6}$ Inspection and surveillance action programs carried out in a coordinated manner among related institutions and security bodies of the three government levels, with the purpose of preventing and inhibiting possible illegal forest activities in areas of high incidence and risk nationwide (critical forest areas).
}

en la zona bajío del país, señalando la falta de recursos económicos y materiales como obstáculos para poder desempeñar de manera adecuada sus funciones, además, la falta de capacitación como otro problema. También coincide con lo señalado por Jacobs y Cordova (2005), que para el caso de México los programas de capacitación para inspectores son pocos $\mathrm{y}$ en muchos casos inexistentes, y que cuando existen programas, estos se centran en ayudar a los inspectores a utilizar los manuales de inspección y los procedimientos de seguridad y el equipo de protección.

En materia forestal, en relación con las tres principales funciones de los inspectores, se encontró que las acciones inspección, recorridos y operativos, desde que entró en funciones la Profepa tienden a ser fluctuantes (Cuadro 2). Si bien las inspecciones, principal función de los inspectores, tuvieron en un principio buen comportamiento, el número crece rápidamente hasta alcanzar su máximo en 1997, después de ese año, también de manera oscilante, se observa una tendencia decreciente. Esa tendencia es preocupante, ya que las inspecciones son de vital importancia para proteger los RN, pues es uno de los principales instrumentos para detectar anomalías y castigar a posibles infractores de la legislación ambiental. Para el año 2016 el número de inspecciones cae en más de la mitad del que había en el punto culminante (sin considerar el año en que inició funciones la dependencia). Asimismo, la relación entre las inspecciones realizadas tiene una clara tendencia decreciente, alcanzando su punto mínimo 
decreases. In practical terms, although operations are part of inspection and surveillance, they do not necessarily result in the detention or securing of forest raw materials, or in penalties for possible offenders, which is the opposite of what happens with inspections; therefore, carrying out too many operations could reduce the number of direct inspections to be carried out.

The number of complaints in forestry matters (a tool that every person or social group has to inform PROFEPA of any fact that produces or could produce damage to NRs, and which are received and dealt with by the inspectors as part of their functions) has a decreasing trend (Figure 1). Although this may seem like good news, since it could allow the inspectors to focus on their other functions and because it could mean that damage to forest resources is decreasing, one might ask why clandestine logging is increasing instead of decreasing, as mentioned in previous sections. This is a fact that should be taken with due caution, since violence by organized groups in the country is high (in 2010 there were 25,757 deaths from homicides and by 2016 there were 24,559$)^{7}$, and many activities by criminal groups tend to take place in forested areas, showing that drug trafficking can have a direct impact on deforestation and trafficking of NRs. For this reason, and given the climate of growing insecurity in the country, it could be a factor

${ }^{7}$ INEGI. Mortality: Data set: Deaths by homicides. In: http://www.inegi.org.mx/lib/olap/consulta/general_ ver4/MDXQueryDatos.asp?proy= en 2016, donde cada inspector realizó un menor número de inspecciones.

Respecto a los recorridos de vigilancia, hubo tendencias cíclicas, de 1995 a 1998 decreciente, para 1999 crecer hasta alcanzar el máximo en 2001, y posteriormente mostrar una tendencia cíclica decreciente, en los que se pueden resaltar los años 2003, 2004, 2005 y 2006 donde los recorridos de vigilancia fueron particularmente bajos (mientras que las inspecciones aumentaron). Sobre los operativos ${ }^{6}$, la menor cantidad fue en el año que entró en funciones la Profepa y la mayor cantidad fue en 1999. Existe un periodo en que estos fueron particularmente altos, de 1997 al 2000; después de este último año la cantidad de operativos fue inferior a los realizados en el periodo antes señalado.

Se corrió una correlación parcial entre inspecciones con recorridos y operativos, con el fin de comprender exactamente la relación entre las variables de interés. Obteniéndose un coeficiente entre inspecciones y operativos de - 0.44 que es significativo al $95 \%$, es decir, existe una relación negativa entre estas dos variables cuando una se incrementa la otra disminuye. Lo que, en términos prácticos, si bien los operativos forman parte de la inspección y vigilancia, estos no necesariamente concluyen con la detención o aseguramiento

\footnotetext{
${ }^{6}$ Programas de acciones de inspección y vigilancia que se realizan de manera coordinada entre instituciones afines y cuerpos de seguridad de los tres órdenes de gobierno con el propósito de frenar e inhibir posibles ilícitos forestales en zonas de alta incidencia y riesgo a nivel nacional (zonas críticas forestales).
} 
Figure 1. Complaints on forest issues addressed per year, from 2010 to 2016.

Gráfica 1. Denuncias atendidas en materia forestal por año, del 2010 al 2016

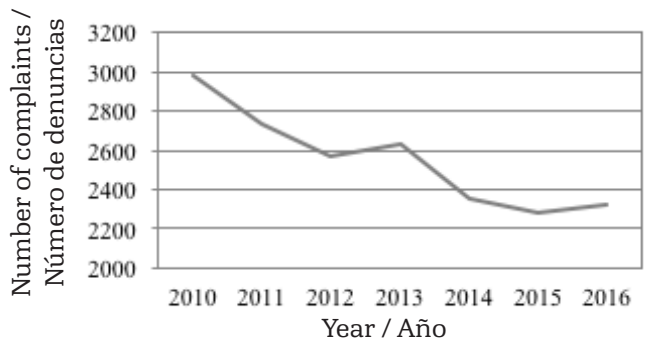

Source: Prepared by authors with information obtained from LFTAIP (2017).

Fuente: Elaboración propia con información obtenida a través de la LFTAIP (2017).

that leads communities and people close to the events not to complain, since in the absence of protection by the authorities towards them, in the least of cases they will be intimidated by the criminals and at the other extreme they could lose their lives (UN, 2016 and 2017).

In the absence of official periodic data on the total growth or decline of forest areas to contrast with the number of inspectors, the PNA data were used to analyze the ratio of hectares of these areas to the total number of inspectors as an approximation. From 2006 to 2009 the number of hectares that each inspector should monitor increased (Figure 2). This situation could be because: 1) the number of inspectors decreased or 2) the PNA area increased. Logic indicates more the second situation, since the PNAs grew in those years (2006-2009) (Figure 3), while the number of inspectors remained more or less stable (Figure 4). By 2010, the number of hectares to be monitored per inspector fell, which is due, according to our de materias primas forestales, o con sanciones para posibles infractores, caso contrario a lo que sucede con las inspecciones; por lo que el realizar demasiados operativos podría disminuir la cantidad de inspecciones directas a realizar.

Sobre las denuncias en materia forestal (herramienta que tiene toda persona o grupo social para informar a Profepa todo hecho que produzca o pueda producir daños a los RN, y que son recibidas y atendidas por los inspectores como parte de sus funciones), tienen una tendencia decreciente (Gráfica 1). Aunque pareciera buena noticia, pues podría permitir a los inspectores enfocarse en sus otras funciones y porque podría significar que los daños a los recursos forestales están disminuyendo, cabría preguntarse por qué la tala clandestina en vez de disminuir está incrementando, como se mencionó en secciones anteriores. Dato que tendría que tomarse con las debidas precauciones, pues la violencia de grupos organizados en el país es alta (en 2010 hubo 25757 defunciones por homicidio y para 2016 fueron 24559$)^{7}$, y muchas actividades de los grupos criminales tienden a realizarse en zonas boscosas, evidenciando que el tráfico de drogas puede incidir directamente en la deforestación y tráfico de RN. Por tal motivo, y dado el clima de inseguridad creciente en el país, podría ser un factor que lleve a que comunidades y personas cercanas a los hechos no denuncien,

\footnotetext{
${ }^{7}$ INEGI. Mortalidad: Conjunto de datos: Defunciones por homicidios. En: http://www.inegi.org.mx/lib/olap/consulta/ general_ver4/MDXOueryDatos.asp?proy=
} 
Figure 2. PNA hectares with respect to the number of inspectors

Gráfica 2. Hectáreas de ANP con respecto al número de inspectores.

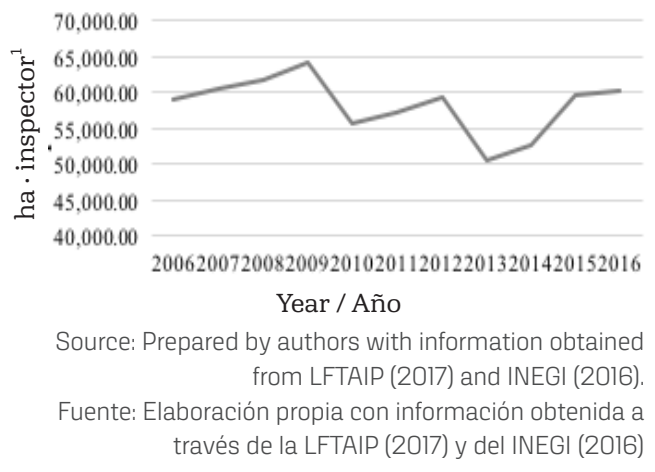

parameters, to the increase in the number of inspectors that year (Figure 4), since, although the number of PNAs was growing, it was still low. From 2011, the ratio of PNAs to inspectors varied due to changes in the number of inspectors, since PNAs remained almost constant between 2011 and 2016 (Figure 2). The number of inspectors for this period reached a peak in 2013, although from that year onwards the number decreased (Figure 4). The above is reflected in Figure 2, which shows that in 2013 each inspector had the lowest number of PNAs to supervise and from then on it increased. It is worth mentioning that, as a result of the interviews with inspectors, there is a perception that staffing is low, given the number of functions and tasks to be performed. Specifically, one noted: “...the institutions are overwhelmed given the environmental problems; there are very few staff to cover these areas."

In 2010, the loss of other wooded areas and forest areas within the national territory
Figure 3. Hectares of PNA.

Figura 3. Hectáreas de ANP

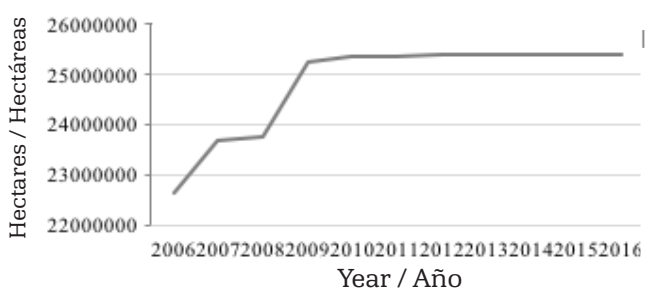

Source: Prepared by authors with information obtained from INEGI (2016).

Fuente: Elaboración propia con información obtenida del INEGI (2016).

Figure 4. Number of inspectors

Figura 4. Número de inspectores

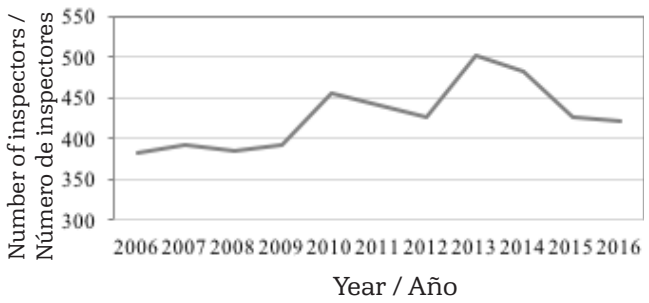

Source: Prepared by authors with information obtained from LFTAIP (2017).

Fuente: Elaboración propia con información obtenida a través de la LFTAIP (2017).

pues al no haber protección por parte de las autoridades hacia ellos, en el menor de los casos serán amedrentados por los delincuentes y en el otro extremo podrían perder la vida (UN, 2016 y 2017).

Al no haber datos periódicos oficiales sobre el crecimiento o decrecimiento total de zonas forestales para contrastar con el número de inspectores, se recurrió al dato ANP para analizar la relación hectáreas de 
again increased (Table 1). The functions of the inspectors include not only monitoring compliance with the legislation within PNAs, but also monitoring compliance with forest legislation throughout the country, where PNAs represent only about $10 \%$ of the national territory, while forestland covers just over $70 \%$. The exercise with the PNAs therefore contributes only to pointing out a situation in a small part of the country; if, on the other hand, the exercise was applied at the national level, the results would be very concerning.

Finally, it can be seen that inspections should come under increasing scrutiny because the high costs of poor inspection practices affects the economic performance and the quality of governance. In our case, as an approach to the problem, the inspectors-budget relationship was considered through what is known as band regression, making it possible to "explore the possible functional relationship between two variables" (Escobar, Fernández, \& Bernardi, 2009: 366), with the purpose of observing whether the budget is related to the number of inspectors. A positive relationship was determined, that is, the number of inspectors is directly related to the budget granted to the institution (Figure 5). However, the real cost of inspections to the State, given their effectiveness and the type of results they are obtaining, is still pending, as the necessary data is not available.

\section{CONCLUSIONS}

The lack of resources for training, materials and travel expenses, among others, has resulted in poor instruction for ins- esas áreas respecto al número de inspectores totales como una aproximación. Del año 2006 al 2009 la cantidad de hectáreas que debiera vigilar cada inspector aumenta (Gráfica 2). Situación que pudiera deberse a: 1) que el número de inspectores disminuyó o 2) que el área de ANP incrementó. La razón va más por la segunda situación, pues las ANP crecieron en esos años (20062009) (Gráfica 3), mientras que la cantidad de inspectores se mantuvo más o menos estable (Gráfica 4). Para el año 2010 la cantidad de hectáreas a vigilar por inspector cae, lo cual se debe, según nuestros parámetros, al aumento de inspectores que se dio ese año (Gráfica 4), pues, aunque crecen las ANP, lo hacen de manera exigua. A partir del año 2011, la relación ANP-inspectores varía por cambios en el número de inspectores, pues las ANP se mantienen casi constantes entre 2011 y 2016 (Grafica 2). El número de inspectores para ese periodo encuentra un punto culminante en el año 2013, aunque a partir de ese año el número decrece (Gráfica 4). Lo anterior se ve reflejado en la Gráfica 2 , en el año 2013 cada inspector tiene la menor cantidad de ANP que supervisary a partir de ahí aumenta. Cabe mencionar que, producto de las entrevistas a inspectores, existe la percepción que el personal es bajo, dada la cantidad de funciones y tareas a realizar. En específico uno señaló: “... están rebasadas las instituciones dados los problemas ambientales; hay muy poco personal para cubrir esas extensiones".

En el año 2010 se vuelve a incrementar la pérdida de otras zonas boscosas y de zonas boscosas dentro del territorio nacional (Cuadro 1). Entre las funciones de los inspectores no solo se encuentra supervisar 
Figure 5. Number of inspectors with respect to the budget.

Gráfica 5. Número de inspectores con respecto al presupuesto.

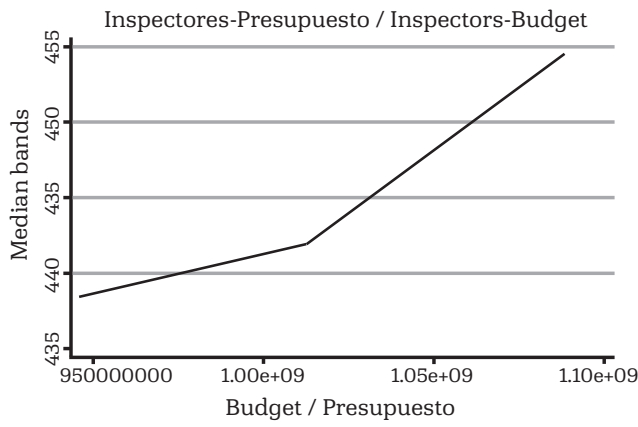

Source: Prepared by authors with information obtained from LFTAIP (2017).

Fuente: Elaboración propia con información obtenida a través de la LFTAIP (2017).

pectors on topics such as identification of forest species and their proper management or techniques for valuing confiscated timber. It could also limit the use of instruments that could be extremely useful when in the field, such as equipment for measuring, georeferencing, taking images, etc., as well as limit the number of on-site inspections for verifying compliance with legislation. In this sense, the International Labour Organization (ILO) states that a recurring problem in these cases is: "the lack of an administrative career, the need for a more adequate salary, job instability, and the recurrent lack of initial or continuous training (which is common in all countries), which is sometimes linked in a collateral way with deontological problems" (OIT, 2013: 11).

Regarding the performance of the inspectors, the efficiency they showed in the el cumplimento de la legislación dentro de ANP, sino también vigilar el cumplimento de la legislación en materia forestal en todo el país, donde las ANP representan aproximadamente solo el $10 \%$ del territorio nacional, mientras que, el terreno forestal abarca poco más del 70 $\%$. Por tanto, el ejercicio con las ANP contribuye a solo señalar una situación que si se considera a escala nacional se tendría que potencializar, con resultados más que preocupantes.

Por último, se advierte que las inspecciones debieran ser objeto de un escrutinio creciente a medida que los altos costos de las malas prácticas de inspección afectan el desempeño económico y la calidad de la gobernanza. En nuestro caso, como una aproximación a la problemática, se consideró la relación inspectores-presupuesto, mediante lo que se conoce como regresión por bandas que posibilita "explorar la posible relación funcional entre dos variables" (Escobar, Fernández, \& Bernardi, 2009: 366), con el propósito de observar si el presupuesto está relacionado al número de inspectores. Se determinó una relación positiva, es decir, el número de inspectores está directamente relacionado al presupuesto que se otorga a la institución (Gráfica 5). Aunque, aún quedaría pendiente, al no contar con los datos necesarios, el costo real de las inspecciones al estado dada su eficacia y la clase de resultados que están entregando.

\section{CONCLUSIONES}

La carencia de recursos para capacitación, materiales y viáticos, entre otros, han 
first years of their work -since PROFEPA started to operate- decreased over the years in terms of number of inspections, visits and operations carried out. Although we can recognize the government initiatives to increase protected areas or PNAs, the personnel with functions to apply the legislation for their care was surpassed in the ratio of supervision per hectare, that is to say, each inspector has had to watch over more and more hectares, which added to the other problems found considerably diminishes their main work. It can be inferred from this that fewer and fewer forest areas or activities are being inspected, which means that a large part of Mexico's forest and protected natural areas, which together constitute $70 \%$ of the country's total territory, are being neglected.

End of English version

\section{REFERENCES/REFERENCIAS}

Altomonte, H., \& Sánchez, R. (2016). Hacia una nueva gobernanza de los recursos naturales en América Latina y el Caribe. Ed. CEPAL, Santiago de Chile.

Arriola-Padilla, V. J., Estrada-Martínez, E., Medellín-Jiménez, R., Ortega-Rubio, A. M., Pikus Rendón, \& Espitia, Moreno, i. C. (2015). "Áreas Naturales Protegidas del Centro de México: Degradación y Recomendaciones". En: Ortega-Rubio, A., M. J. Pinkus-Rendón y I. C. Espitia-Moreno (comp.). Las Áreas Naturales Protegidas y la Investigación Científica en México. Ed. Centro de Investigaciones Biológicas del Noroeste S. C., La Paz B. C. S., Universi- repercutido en la falta de instrucción adecuada a los inspectores en temas como la identificación de especies forestales y su adecuado manejo o técnicas para valorar la madera en troza decomisada, también podría limitar el uso de instrumentos que podrían ser de suma utilidad a la hora de estar en campo, como equipo para medir, georreferenciar, tomar imágenes, etc., e igualmente limitar las salidas a verificar el cumplimiento de la legislación. En este sentido la Organización Internacional del Trabajo (OIT) determina que un problema recurrente es en estos casos: "la falta de carrera administrativa, la necesidad de un salario más adecuado, la inestabilidad en el empleo, y la falta recurrente de ausencia de formación inicial o continua (que es común en todos los países), lo que a veces se liga de forma colateral con problemas deontológicos" (OIT, 2013: 11).

Sobre el desempeño de los inspectores, la eficiencia que mostraron en los primeros años de su labor -desde que entró en operaciones la Procuraduría- fue disminuyendo con el paso de los años en lo referente al número de inspecciones, recorridos y operativos realizados. Si bien, podemos reconocer las iniciativas del gobierno a incrementar las zonas protegidas o ANP, el personal con funciones para aplicar la legislación para su cuidado fue superado en la relación supervisión por hectáreas, es decir, cada inspector ha tenido que vigilar cada vez más hectáreas, lo que aunado a las otras problemáticas encontradas merma considerablemente su labor principal. De ello se puede entrever que cada vez son menos las zonas o actividades forestales inspeccionadas, 
dad Autónoma de Yucatán, Mérida, Yucatán y Universidad Michoacana de San Nicolás de Hidalgo, Michoacán, México, pp. 337-374.

Blanc, F. (2012). Inspection reforms: why, how, and with what results. Ed. OECD. https://www.oecd.org/regreform/Inspection\%20reforms\%20-\%20web\%20 -F.\%20Blanc.pdf

Comisión Nacional Forestal (Conafor). (2014). Boletín 23. Ed. Semarnat/Conafor, México. http://www.conafor.gob.mx:8080/documentos/docs/7/5297En\%20M\%C3\%A9xic o $\% 20$ hay $\% 2016 \% 20$ millones $\% 20$ de\%20hect\%C3\%A1reas\%20de\%20terrenos\%20forestales\%20susceptibles\%20 a\%20la\%20reforestaci\%C3\%B3n.pdf

Consejo Nacional de Evaluación de la Política de Desarrollo Social (CONEVAL). (2014). Diagnóstico del programa G005, Programa de Inspección y Vigilancia en materia de Medio Ambiente y Recursos Naturales. Ed. CONEVAL, México. https://www. coneval.org.mx/Informes/Evaluacion/ Diagnostico/Diagnostico_2014/Diagnostico_2014_SEMARNAT_G005.pdf

de Castro, F., Hogenboom, B., \& Baud, M. (2015). "Introducción". En: de Castro, Fabio; Hogenboom, Barbara y Baud, Michiel (Coor). Gobernanza ambiental en América Latina. Ed. CLACSO; ENGOV, Buenos Aires, Argentina, pp. 13-38.

Escobar, M., Fernández, E., \& Bernardi, F. (2009). Cuadernos Metodológicos. Ed. Centro de Investigaciones (CIS), Madrid, España.

Espitia-Moreno, I., Jiménez-Sierra, C., \& Ortega-Rubio, A. (2015). "Informes de Responsabilidad Social en las Áreas Naturales Protegidas de México". En: Ortega-Rubio, A., M. J. Pinkus-Rendón y I. C. Espitia-Moreno con lo que, se estaría descuidando parte importante del $70 \%$ de la zona forestal que hay en el país, incluyendo las zonas que abarcan las ANP.

Fin de la versión en español

(comp.). Las Áreas Naturales Protegidas y la Investigación Científica en México. Ed. Centro de Investigaciones Biológicas del Noroeste S. C., La Paz B. C. S., Universidad Autónoma de Yucatán, Mérida, Yucatán y Universidad Michoacana de San Nicolás de Hidalgo, Michoacán, México, pp. 179-194.

Food and Agriculture Organization (FAO). (2010a). "Observancia de la legislación forestal". En: http://www.fao.org/forestry/ law/es/ consultado el 28 de noviembre del 2018.

Food and Agriculture Organization (FAO). (2010b). "Forest Law Enforcement". En: http://www.fao.org/forestry/law/en/ consultado el 28 de noviembre del 2018

Food and Agriculture Organization (FAO). (2015). Evaluación de los recursos forestales mundiales 2015; Compendio de datos. Roma, Italia. FAO. http://www.fao. org/3/a-j4808s.pdf.

Food and Agriculture Organization (FAO). (2016). Evaluación de los recursos forestales mundiales 2015; ¿Cómo están cambiando los bosques del mundo? Ed. FAO, Roma, Italia. http://www.fao.org/3/a-i4793s.pdf

Foro Ambiental. (2017). “Tala ilegal de árboles en México es alarmante”. En: https://www. foroambiental.com.mx/tala-ilegal-de-arboles-en-mexico-es-alarmante/ consultado el 5 de septiembre de 2018.

Galicia, L. (2013). "México pierde cada año 40 
mil hectáreas de bosques templados". En http://www.dgcs.unam.mx/boletin/bdboletin/2013_757.html consultado el 7 de octubre de 2018.

Global Forest Watch. (2016). "Country Rankings for Tree Cover, Tree Cover Loss, and Tree Cover Gain". En: https://www.globalforestwatch.org/ consultado el 3 de octubre del 2018).

Guinart i Solà, J. M. (2003). "Indicadores de gestión para las entidades públicas". Ponencia presentada en el VIII Congreso Internacional del CLAD sobre la Reforma del Estado y de la Administración Pública, Panamá. http://unpan1.un.org/intradoc/groups/public/documents/CLAD/ clad0047601.pdf

Hernández Meza, M. de L. (2012). La gobernanza ambiental y los nuevos retos de la procuraduría federal de protección al ambiente. Ed. Instituto de Investigaciones Jurídicas de la UNAM/UNAM, Ciudad de México https://archivos.juridicas.unam. mx/www/bjv/libros/7/3177/6.pdf

Instituto Nacional de Estadística y Geografía (INEGI). (2016). Anuario estadístico y geográfico por entidad federativa 2016. Ed. INEGI, México. http://internet.contenidos.inegi.org.mx/contenidos/productos/prod_serv/contenidos/espanol/ bvinegi/productos/nueva_estruc/AEGPEF_2016/702825087357.pdf

Instituto Nacional de Estadística y Geografía (INEGI). (2017a). "Volumen y valor de la producción forestal maderable según principales especies, 2005 a 2016". En: http://www.inegi.org.mx/ consultado el 15 de noviembre del 2018.

Instituto Nacional de Estadística y Geografía (INEGI). (2017b). Anuario estadístico y geográfico de los Estados Unidos Mexica- nos 2017. Ed. INEGI, México. http://internet.contenidos.inegi.org.mx/contenidos/ Productos/prod_serv/contenidos/espanol/bvinegi/productos/nueva_estruc/ AEGEUM_2017/702825097912.pdf

Scott, J., \& Cordova, C. (2005). Good Practices for Regulatory Inspections: Guidelines for Reformers. Ed. World Bank Group. http:// www.fao.org/3/a-at377e.pdf

Ley Federal de Transparencia y Acceso a la Información Pública. (2017). Diario Oficial de la Federación, México. http://www. diputados.gob.mx/LeyesBiblio/pdf/ LFTAIP_270117.pdf

Lezama, J. L. (2010). “Sociedad, medio ambiente y política ambiental, 1970-2000.. En Lezama, José Luis y Boris Graizbord (coord.). Los grandes problemas de México. IV Medio Ambiente. Ed. El Colegio de México, México, pp. 23-60.

Monk, J. (2012). Reform of regulatory enforcement and inspections in OECD countries. Ed. OECD. https://www.oecd.org/regreform/Reform\%20of\%20inspections $\% 20$ -\%20Web\%20-\%20Julie\%20Monk.pdf

Organization for Economic Cooperation and Development. (OECD). 2004. Assuring environmental compliance. A toolkit for building better environmental inspectorates in Eastern Europe, Caucasus, and Central Asia. Ed. OECD, París. https://www. oecd.org/env/outreach/34499651.pdf

Organization for Economic Cooperation and Development. (2014a). Regulatory Enforcement and Inspections, OECD Best Practice Principles for Regulatory Policy. Ed. OECD. DOI: 10.1787/9789264208117-en

Organization for Economic Cooperation and Development. (2014b). The governance of regulators, best practice principles on regulatory policy. Ed. OECD, Paris. DOI: 


\subsection{7/9789264209015-en}

Organization for Economic Cooperation and Development. (2018). OECD Regulatory Enforcement and Inspections Toolkit. Ed. OECD, Paris. DOI: 10.1787/9789264303959-en

Organización Internacional del Trabajo (OIT). (2013). El papel de la administración y la inspección del trabajo en la gobernanza en las américas. Ed. OIT, Lima. http://scm.oas. org/pdfs/2013/CIDI/CIDI04187S01.pdf

Ortega-Rubio, A., Pinkus-Rendón, M. J., \& Espitia-Moreno, I. C. (2015). Las Áreas Naturales Protegidas y la Investigación Científica en México. Ed. Centro de Investigaciones Biológicas del Noroeste S. C., La Paz B. C. S., Universidad Autónoma de Yucatán, Mérida, Yucatán y Universidad Michoacana de San Nicolás de Hidalgo, Michoacán, México.

Pautz, M. C. (2009). "Trust between regulators and the regulated: a case study of environmental inspectors and facility personnel in Virginia”. En: Politics \& Policy, 37(5): 1047-1072. DOI: 10.1111/j.17471346.2009.00210.x

Pautz, M. C., \& Rinfret, S. R. (2011). "Making sense of the front lines: environmental regulators in Ohio and Wisconsin". En: Journal of Environmental Studies and Sciences, 1(4): 277-288.

Procuraduría Federal de Protección al Ambiente (Profepa). (2010). "Guía de derechos y obligaciones de los inspeccionados". En: http://www.profepa.gob.mx/innovaportal/v/1369/1/mx.wap/guia_de_derechos_y_ obligaciones_de_los_inspeccinados.html consultado el 27 de octubre del 2018.

Reglamento interior de la Secretaría de Medio Ambiente y Recursos Naturales (Semar- nat). (2012). Diario Oficial de la Federación. México. http://www.profepa.gob.mx/innovaportal/file/1169/1/reglamento_interior_semarnat_26-11-2012_pdf.pdf

Secretaría de Medio Ambiente y Recursos Naturales (Semarnat). (2018). "Biodiversidad". https://www.gob.mx/ consultado el 02 de noviembre del 2018.

Torres-Rojo, J. M. (2004). "Estudio de tendencias y perspectivas del sector forestal en América Latina al año 2020 (Informe Nacional México)". Ed. FAO, Roma, Italia. En: http://www.fao.org/docrep/006/j2215s/ j2215s06.htm consultado el 30 de octubre del 2018.

United Nations (UN). 2016. World Drug Report. 2016. New York: UN. https://www. unodc.org/wdr2016/WORLD_DRUG_REPORT_2016_web.pdf

United Nations (UN). 2017. World Drug Report. 2017. New York: UN. https://www.unodc. org/doc/wdr2017/index.html consultado el 27 de noviembre del 2018.

United Nations (UN). (2018a). "United Nations Environment Programme: Forests". En: https://www.unenvironment.org/explore-topics/forests consultado el $01 \mathrm{de}$ diciembre del 2018.

United Nations (UN). (2018b). "Fortaleciendo la gobernanza ambiental”. En: https://www. unenvironment.org/es/regiones/america-latina-y-el-caribe/iniciativas-regionales/ fortaleciendo-la-gobernanza-ambiental-1 consultado el 02 de diciembre del 2018.

Wingqvist, G. Ö., Slunge, D., Drakenberg, O., Sjöstedt, M., \& Ekbom, A. (2012). The role of governance for improved environmental outcomes Perspectives for developing countries and countries in transition. Ed. Swedish Environmental Protection Agen- 
